\title{
Alternative Substrate and Recipients for the Production of Arabica Coffee Seedlings
}

\author{
Mario Euclides Pechara da Costa Jaeggi ${ }^{1}$, Richardson Sales Rocha ${ }^{1}$, Israel Martins Pereira ${ }^{1}$, \\ Derivaldo Pureza da $\mathrm{Cruz}^{2}$, Rita de Kássia Guarnier da Silva ${ }^{1}$, Josimar Nogueira Batista ${ }^{1}$, \\ Magno do Carmo Parajara ${ }^{3}$, Rogério Rangel Rodrigues ${ }^{4}$, Geovana Cremonini Entringer ${ }^{2}$, \\ Geraldo de Amaral Gravina ${ }^{1,2}$, Rogério Figueiredo Daher ${ }^{1,2}$ \& Wallace Luís de Lima ${ }^{5}$ \\ ${ }^{1}$ Postgraduate Program in Plant Production, State University of North Fluminense, Campos dos Goytacazes, RJ, \\ Brazil \\ ${ }^{2}$ Postgraduate Program in Plant Breeding, State University of North Fluminense, Campos dos Goytacazes, RJ, \\ Brazil \\ ${ }^{3}$ Teaching, Research and Extension Council, Federal University of Viçosa, Viçosa, MG, Brazil \\ ${ }^{4}$ Federal Institute of Education, Science and Technology of Pará, Brazil \\ ${ }^{5}$ Postgraduate Program in Agroecology, Federal Institute of Espírito Santo, Alegre, ES, Brazil \\ Correspondence: Richardson Sales Rocha, Postgraduate Program in Plant Production, State University of North \\ Fluminense, Av. Alberto Lamego, 2000. Parque California, 28035-200, Campos dos Goytacazes, RJ, Brazil. \\ E-mail: richardson_sales@hotmail.com
}

Received: January 14, 2020

Accepted: March 5, 2020

Online Published: April 15, 2020

doi:10.5539/jas.v12n5p82

URL: https://doi.org/10.5539/jas.v12n5p82

\begin{abstract}
The present work aimed to assess the quality of arabica coffee seedlings produced on different substrates and in various recipients. The work was performed in a randomized block experimental design, using three repetitions, in subdivided parcels, with three parcels, and four sub parcels. The experiment used the cultivar of Coffea arábia "Catuai IAC 44". The genotype received the following treatments: R1 polyethylene bag, $615 \mathrm{~cm}^{3} ; \mathrm{R} 2: 280 \mathrm{~cm}^{3}$ tubes; R3: $120 \mathrm{~cm}^{3}$ tubes; $\mathrm{S} 1$ conventional substrate composed by a mixture of ravine earth with bovine manure at a 3:1 (v/v) proportion added with a NPK fertilization, recommended for coffee culture; S2 organic leguminous compound, mixture of a leguminous plant (guandu beans, Cajanus cajan) with bovine manure at a 1:1 (v/v) proportion, followed by a 90 days maturation process; S3: organic grass compound, produced by the composting of garden grass chips mixed with bovine manure at 1:1 proportion; and S4: vermicompost derived from the organic decompositions of grasses. The results of this research highlight that substrates and recipients affect the development of the seedlings of arabica coffee, improving the quality indexes of Dickson in the higher volume $615 \mathrm{~cm} 3$ recipient and the alternative substrate composed by legume, grass, and vermicompost were efficient to produce Arabica coffee seedlings. This combination of substrate and recipient can substitute the conventional substrate in this phase of the development of the seedlings, providing an increase in the production quality.
\end{abstract}

Keywords: Coffea arábia, quality, coffee culture, quality index

\section{Introduction}

The coffee culture in Brazil is considered to be of high productivity, due to the high technological level used in its production, requiring renovation and handling of the crop for modern planting systems (Dardengo et al., 2013). The use of good quality seedlings is decisive in the succession process of coffee parks. The volume provided by the container and the substrate used directly influences the quality of the seedlings (Jaeggi et al., 2018). The substrate has fundamental importance to the good germination consequently emergence of platelets, adequate availability of nutrients and oxygen and $\mathrm{CO}_{2}$ elimination. In addition to the good water retention capacity, so that there is a relevant physiological process for the twinning and phenological development (Meneghelli et al., 2018).

The acquisition of vigorous coffee seedlings is crucial to compose a productive area. This element is essential to establish a productive and sustainable agriculture with reduced costs (Dardengo et al., 2013). Some of the criteria to avoid such loss and evaluation of the crucial characteristics related to the vigor of the coffee seedling are the 
thick stem, the root system with abundant absorbent roots and the green and shiny leaves (Oliveira \& Miglioranza, 2015). The most traded types of seedlings are produced in plastic containers with a volume of 615 $\mathrm{cm}^{3}$ of polyethylene with substrate contained in its soil, livestock manure enriched with chemical macro and micronitrients and those produced in tubes with a capacity of $280 \mathrm{~cm}^{3}$ and $120 \mathrm{~cm}^{3}$ of polyethylene with commercial substrate (Meneguelli et al., 2016).

The use of organic waste as a substrate for the production of coffee seedlings is considered a viable alternative, since they are normally rich in nutrients and produced in large quantities by rural properties, and their destination is a constant problem for the environment. Vegetable remains in general and varied manure such as cattle, goats, sheep, and poultry are great alternatives for substrate composition due to attributes such as good drainage, high porosity and presence of micropores, responsible for good aeration and water retention beyond the source potassium and nitrogen (Krauser et al., 2017).

Polyethylene tubes and bags should be pointed between the containers currently used in the commercial production of coffee seedlings. Most of the farm prefers the use of tubes, due to the ease of handling, the smaller space they occupy and the economy in the use of the substrate. It is worth noting that the substrate represents $38 \%$ of the cost of producing coffee seedlings (Vallone et al., 2010). The use of organic material derived from the creation of animals in confinement, such as cattle, pigs, birds and rabbits, can reduce the production cost of farmers. Some works have already discussed the use of different sources of organic matter in the production of coffee in tubes. Organic materials such as vermiculite, organic matter and earthworm humus provided benefits in the production of coffee seedlings (Jaeggi et al., 2018; Meneghelli et al., 2016).

Given the above, the objective of this work was to evaluate the effects of different substrates and containers on the production of Arabica coffee seedlings.

\section{Method}

The experiment was performed in a seedling production farm covered by a $50 \%$ shadow at the Federal Institute of the State of Espirito Santo (IFES), Brazil, Campus of the city of Alegre $\left(20^{\circ} 45^{\prime} 44^{\prime \prime} \mathrm{S}, 41^{\circ} 27^{\prime} 43^{\prime \prime} \mathrm{W}\right.$, altitude $134 \mathrm{~m}$ above the sea level). According to the Köppen classification, the climate of the region is "Aw" type, with dry winter, and rainy summer, average year temperature of about $23{ }^{\circ} \mathrm{C}$, and average rainfall of about $1.200 \mathrm{~mm}$.

The work was performed in a randomized block experimental design, using 3 repetitions, in subdivided parcels, with three parcels, and four sub parcels. The cultivar of Coffea arábia used in the experiment was the "Catuai IAC 44". Seeds acquisition was performed during the post-harvest stage at the farm, selecting riped and healthy grains, displaying the maximum physiological development. In each container, two seeds were placed at $1.0 \mathrm{~cm}$ depth. Thinning was performed just after the appearance of the first pair of real leaves, eliminating the less vigorous plants (Matiello et al., 2010). The irrigation was performed twice a day through the use of spray nozzles during the 160 days of the experiment.

The experiment was performed using different substrates and recipients for the production of the seedlings. The genotype received the following treatments: R1: $615 \mathrm{~cm}^{3}$ polyethylene bag; R2: $280 \mathrm{~cm}^{3}$ tubes; R3: $120 \mathrm{~cm}^{3}$ tubes; S1 conventional substrate composed by a mixture of ravine earth with bovine manure at a 3:1 (v/v) proportion added with a NPK fertilization, recommended for coffee culture (Prezotti et al., 2013) S2 organic leguminous compound, mixture of a leguminous plant (guandu beans, Cajanus cajan) with bovine manure at a 1:1 (v/v) proportion, followed by a 90 days maturation process; S3: organic grass compound, produced by the composting of garden grass chips mixed with bovine manure at 1:1 proportion (Souza et al 2013) and S4: vermicompost derived from the organic decompositions of grasses. Substrates were characterized by chemical analysis at the soil fertility laboratory of the soils department of the Rural Federal University of Rio de Janeiro (UFRRJ) (Table 1).

Table 1. Chemical characterization of the substrates used in the production of the coffee seedlings

\begin{tabular}{llllllll}
\hline Substrates & $\mathrm{N}$ & $\mathrm{P}_{2} \mathrm{O}_{5}$ & $\mathrm{~K}_{2} \mathrm{O}$ & $\mathrm{Mg}$ & $\mathrm{Ca}$ & $\mathrm{C}$ & $\mathrm{pH}$ \\
\hline & ----------- & $\mathrm{g} / \mathrm{kg} \mathrm{mg} \mathrm{dm}^{-3}---------$ & $----\mathrm{cmol}_{\mathrm{c}} \mathrm{dm}^{-3}----$ & $\mathrm{g} \mathrm{kg}^{-1}$ & water \\
S1 & 18 & 38 & 18.07 & 5 & 26 & 40.7 & 6.2 \\
$\mathrm{~S} 2$ & 33 & 28.1 & 15.36 & 5.7 & 2.9 & 158 & 8.8 \\
$\mathrm{~S} 3$ & 15 & 16 & 30.6 & 5.3 & 27.9 & 62 & 7.4 \\
$\mathrm{~S} 4$ & 15 & 36.3 & 36.72 & 7.9 & 5.3 & 113 & 6.7 \\
\hline
\end{tabular}

Note. S1 convencional; S2 leguminous compound + bovine manure; S3 gramine compound + bovine manure; S4 vermicompost. 
The assessments were performed at 165 days after seeding. The variables studied were: Dry mass of the aerial part and root $\left(\mathrm{g} \mathrm{Plant}^{-1}\right)$ : measured using digital scale after drying in a forced circulation stove at $75^{\circ} \mathrm{C}$ until stabilization of the weight. Number of leaves: obtained by the direct counting of the leaves. Height of the aerial part $\left(\mathrm{cm} \mathrm{Plant}^{-1}\right)$ : determined by a millimeter scale, considering the region included between the plant collar and the apical bud of the coffee plant. Leaf area $\left(\mathrm{cm}^{2}\right.$ Plant $\left.^{-1}\right)$ : measured by the mathematical model AF $=0.667$ C.L. (Barros et al., 1973) measuring the width and length of the leaves. Dickson Quality index: obtained by the equation DQI = [Total dry matter/(Relation height/Diameter + Relation aerial part/Root)] (Dickson et al., 1960). Relation aerial part/root ratio: obtained by the equation MSPA/MSR. Height/diameter ratio: obtained by the equation ALT/DC and roots length $\left(\mathrm{cm}\right.$ plant $\left.{ }^{-1}\right)$.

Total nitrogen $\left(\%\right.$ plant $\left.^{-1}\right)$ : estimated by the Kjeldahl method, based on the decomposition of the organic matter through the digestion of the sample at $400^{\circ}$ using concentrated hydrogen sulfide, in the presence of copper sulfate as catalyzer, which accelerates the oxidation of the organic matter. The resulting nitrogen in the acid solution was quantified by steam distillation by trawl, followed by titling using diluted acid (Nogueira \& Souza 2005).

Total raw protein $\left(\%\right.$ plant $\left.^{-1}\right)$ : estimated by the equation PBT $=\mathrm{NT} \times \mathrm{FN}$, where: $\mathrm{NT}$ is the total nitrogen, and FN is the 6.25-factor corresponding to the nitrogen contained in the proteins (Nogueira \& Souza, 2005). The protein rate in the feeds is measured from the nitrogen rate in the analyzed sample. This correction factor bases on the fact that proteins have $16 \%$ nitrogen in their constitution and that all the nitrogen is in the form of proteins (Nogueira \& Souza, 2005). Data were submitted to analysis of variance (ANOVA) and test of the averages. The Scott-Knott test grouped averages values at 5\% significance according to the software SISVAR version 5.3 (Ferreira, 2011).

\section{Results and Discussion}

The analysis of variance displayed significant effects on the factors that have been isolated. As refers to the substrate factor, number of leaves (NF), and total length of the plants (CT); roots length (CR); roots nitrogen (NTR) displayed significant results ( $\mathrm{p} \leq 0.01$ ). The remaining variables did not display significant differences.

Different substrates for seedling production are still needed for alternative visual studies for the producer, since the composition of the substrate can be influenced by several factors such as type of manure, remaining vegetable used that can be used in a short time for chemical and physical composition of the substrate (Vallone et al., 2010).

Dias et al. (2009) adds $40 \%$ of the double bed to the conventional one found and favoring the development of coffee seedlings, while the enamel of the cow, when added to the conventional substrate hampered by the development of seedlings, uses its proportion.

As refers to the recipient factor, Table 2 displays the variables with significant effect at $p \leq 0.05$ : number of leaves (NF); total length of the plant (CT); total fresh mass (MFT); total dry mass (MST); total length of the root (CR); length of the aerial portion (CPA); height/diameter ratio (ALT/DC); Dickson quality index (DQI), and leaf area (AF). Possibly the effect provided by the container factor was expressed by the culture since the reduction of substrate volume through the container may cause competition between the plant organs. Small, weak vigor and little branched roots result in smaller plants, delaying their phenological development, negatively influencing in the field payment rate (Baliza et al., 2013).

The interaction between the effects of the recipient and the substrate was significant for the variables: relation between dry matter of the aerial part, and root (MSPA/MSR), total nitrogen of the aerial part (NTPA) and raw protein of the aerial part (PBPA), as described in the Table 2. The results found reflected a sample that the larger volume of substrate provided greater extractions of nutrients and consequently greater production of roots and part of aerial influence in the quality criteria (Dardengo et al., 2013; Jaeggi et al., 2018).

The dry matter of the aerial part did not display significant differences among the treatments between the recipients R1 and R3 for the different substrates (Table 3). The substrates S1 (4.07 g), and S3 (4.07 g) displayed significant differences from the substrate S2 and S4, which provided a dry matter of the aerial part of respectively $1.59 \mathrm{~g}$, and $3.10 \mathrm{~g}$ each. These results display that the use of an alternative compound as a substrate allows the production of arabica coffee seedlings as well as the use of the traditional compounds as a substrate. These results show the potential of the S3 substrate to substitute the conventional commercial substrate in the production of coffee seedlings. This increase can have a direct relationship to the availability of substrate volume since the roots have more space for root growth, increasing the capacity for extracting nutrients, which allows a greater increase in dry matter from the aerial part (Jaeggi et al., 2018) gains in MSPA and MSRA represent 
improvement in the production of coffee seedlings (Cogo et al., 2011) and, therefore, seedlings with a higher dry matter index should be recommended to the producer in order to increase the vigor of the plant and increase the field payment rate (Baliza et al., 2013).

As refers to the Nitrogen of the aerial part (NTPA), the average results of the R1 recipient with the substrates that used bovine manure in their composition (S1, S2, and S3) were significantly superior to the remaining. As refers to the recipient $\mathrm{R} 2$, the use of the substrates $\mathrm{S} 2$ and $\mathrm{S} 3$ provided significantly higher results $(2.79$ and 2.58 respectively). In the recipient R3, the use of the substrate S1 resulted in significantly higher average values than the remaining substrates $(2.64 \%)$.

The raw protein of the aerial part (PBPA) did not display significant differences among the substrates for the seedlings produced in the R1 container. Substrates S2 and S3 associated with the higher PBPA values in the recipient R2: 17.47 and $16.43 \%$, respectively. Substrates S1, S3 and S4 associated with PBPA values of $16.52 \mathrm{~g}$, $10.25 \mathrm{~g}$, and $10.55 \mathrm{~g}$ in the recipient $\mathrm{R} 3$ respectively.

Our results point out also the effect of the recipient on the development of the Arabica coffee seedlings. Recipient R1, with the highest volume, displayed better average results than R2 and R3, with lower volume. The higher nitrogen value in the plant might be associated with the higher substrate volume, which can be exploited by the root system and the disponibility of this element in the substrate compound. According to Santinato et al. (2014), the addition of nitrogen to the substrate containing bovine manure is fundamental to satisfy the requirement of the seedlings for this nutrient. Even the same, the results of this research highlight that the substrate volume has a significant effect in the nitrogen concentration available for the plant. Higher substrate volume provided higher amounts of nitrogen (Santinato et al., 2014).

Table 2. Summary of the analysis of variance of the analyzed features, with the correspondent $F$ values: Number of leaves (NF) total length of the plants (CT); total fresh mass (MFT); total dry mass (MST); total length of the root (CR); length of the aerial plant (CPA); height/diameter ratio (ALT/DC); Dickson quality index (DQI) leaf area (AF); nitrogen (NTPA) and raw protein of the aerial part (PBPA); nitrogen of the root (NTR) and raw protein of the root (PBR)

\begin{tabular}{|c|c|c|c|c|c|c|c|c|c|c|c|c|c|c|c|}
\hline \multirow{2}{*}{ F.V. } & \multicolumn{15}{|c|}{ Average square } \\
\hline & GL & $\mathrm{NF}$ & $\mathrm{CT}$ & MFT & MST & $\mathrm{CR}$ & $\mathrm{CPA}$ & ALT/DC & MSA/MSR & DQI & $\mathrm{AF}$ & NTPA & NTR & PBPA & PBR \\
\hline Bloc & 2 & 5.02 & 30.36 & 30.84 & 2.61 & 9.5 & 31.6 & 1.7 & 0.09 & 0.004 & 80.8 & 0.59 & 0.35 & 42.80 & 3.10 \\
\hline Sub & 3 & $134^{* *}$ & $32.7^{* *}$ & $34.4^{\mathrm{ns}}$ & $0.88^{\mathrm{ns}}$ & $12.7^{* *}$ & 7.1 & $1.7^{\mathrm{ns}}$ & 2.1 & $0.003^{\mathrm{ns}}$ & $145.1^{\mathrm{ns}}$ & $1.69 * *$ & $1.07 * *$ & $69.92 * *$ & $13.41^{\mathrm{ns}}$ \\
\hline Error 1 & 6 & 2.5 & 2.9 & 11.5 & 0.7 & 1.9 & 3.0 & 0.7 & 0.07 & 0.003 & 35.6 & 0.15 & 0.18 & 20.2 & 13.6 \\
\hline Rec & 2 & $18.1^{*}$ & $1092.2 *$ & $1531.2^{*}$ & $67.2^{*}$ & $181.7^{*}$ & $399.6^{*}$ & $100.1^{*}$ & $7.70^{*}$ & $0.15^{*}$ & $5849.1^{*}$ & $0.75^{*}$ & 0.25 & $19.32 *$ & $18.50^{\mathrm{ns}}$ \\
\hline Sub*Rec & 6 & $0.69^{\mathrm{ns}}$ & $42.7^{\mathrm{ns}}$ & $7.66^{\mathrm{ns}}$ & $1.11^{\mathrm{ns}}$ & $5.9^{\mathrm{ns}}$ & $25.9^{\mathrm{ns}}$ & $6.41^{\mathrm{ns}}$ & $0.91 *$ & $0.004^{\mathrm{ns}}$ & $96.6^{\mathrm{ns}}$ & $1.24 *$ & 0.32 & $64.80^{*}$ & $18.70^{\mathrm{ns}}$ \\
\hline Error 2 & 16 & 3.48 & 17.5 & 41.3 & 1.3 & 6.9 & 9.6 & 2.4 & 0.2 & 0.005 & 44.1 & 0.09 & 0.17 & 17.17 & 26.7 \\
\hline CV $1(\%)$ & & 27.53 & 4.77 & 21.29 & 24.40 & 7.17 & 9.69 & 9.64 & 11.57 & 18.91 & 16.94 & 19.05 & 24.46 & 37.11 & 39.33 \\
\hline CV $2(\%)$ & & 18.30 & 11.63 & 40.33 & 33.13 & 14.76 & 17.19 & 17.15 & 20.05 & 25.90 & 18.86 & 14.92 & 23.41 & 34.20 & 55.09 \\
\hline
\end{tabular}

Note. ${ }^{* *}$ Significant at $(\mathrm{p} \leq 0.01),{ }^{*}$ significant at $(\mathrm{p} \leq 0.05),{ }^{\text {ns }}$ not significant by the test of Tukey.

Table 3. Relation of the dry matter of the aerial part and root (MSPA/MSR), nitrogen (NTPA) and raw protein of the aerial part (PBPA) of coffee seedlings in different substrates and recipients

\begin{tabular}{|c|c|c|c|c|c|c|c|c|c|}
\hline \multirow{2}{*}{$* \mathrm{~S} / \mathrm{R}$} & \multicolumn{3}{|c|}{ MSPA/MSR } & \multicolumn{3}{|c|}{ NTPA $(\%)$} & \multicolumn{3}{|c|}{ PBPA (\%) } \\
\hline & R1 & R2 & R3 & R1 & $\mathrm{R} 2$ & R3 & R1 & $\mathrm{R} 2$ & R3 \\
\hline S1 & $3.06 \mathrm{Aa}$ & $4.07 \mathrm{Aa}$ & $1.55 \mathrm{Ab}$ & $3.04 \mathrm{Aa}$ & $1.66 \mathrm{Bb}$ & $2.64 \mathrm{Aa}$ & $19.00 \mathrm{Aa}$ & $10.38 \mathrm{ABa}$ & $16.52 \mathrm{Aa}$ \\
\hline S2 & $2.24 \mathrm{Aa}$ & $1.59 \mathrm{Ca}$ & $1.35 \mathrm{Aa}$ & $2.70 \mathrm{Aa}$ & 2.79Aa & $1.20 \mathrm{Bb}$ & $12.69 \mathrm{Aab}$ & 17.47Aa & $5.50 \mathrm{Bb}$ \\
\hline S3 & $2.53 \mathrm{Ab}$ & $3.59 \mathrm{ABa}$ & $1.33 \mathrm{Ac}$ & $2.33 \mathrm{Aa}$ & $2.58 \mathrm{Aa}$ & $1.64 \mathrm{Bb}$ & $11.76 \mathrm{Aa}$ & $16.13 \mathrm{Aa}$ & $10.25 \mathrm{ABa}$ \\
\hline S4 & $2.57 \mathrm{Aab}$ & $3.10 \mathrm{Ba}$ & $1.85 \mathrm{Ab}$ & $1.47 \mathrm{Ba}$ & $1.19 \mathrm{Ba}$ & $1.68 \mathrm{Ba}$ & $9.20 \mathrm{Aa}$ & $5.48 \mathrm{Ba}$ & $10.55 \mathrm{ABa}$ \\
\hline
\end{tabular}

Note. Means followed by the the same uppercase letters in the row and lower-case letter in the line do not differ significantly among each other by the Tukey test $(\mathrm{p} \leq 0.05)$. *S: substrate; R: recipients.

The analysis of the isolated factors highlights that the S2 substrate was associated with the lowest average leaves number (NF) (16.22), as displayed in Table 4; and the highest average nitrogen of the root (NR) was associated with the substrate S3. These values were significantly different just from the substrate S4. S2 substrate pointed 
out as refers to the roots length (CR), and total length (CT). This substrate was associated with the highest values of both variables: 19.33 and $38.66 \mathrm{~cm}$ a plant, respectively.

The values observed in Table 4 show the potential that organic substrate has to supply the plant's need, proving effective to highlight some important characters. According to (Soares et al., 2016) the substrate is one of the important components for the formation of quality seedlings, as it relates to structure, moisture retention capacity, aeration, nutrition and other characteristics.

Nogueira et al. (2011) pointed out that there is a significant increase in research related to the substrate, because its composition is due to different materials can generate different results because the main agents that influence the quality of plants and species can respond similarly or not to a specific substrate (Gonçalves et al., 2014).

Thus, it is worth noting that organic matter becomes one of the main components for the subtracts; being able to provide countless benefits with increases the retention of water and nutrients capacity and reduces apparent and general densities (Caldeira et al., 2008). Several authors report that the inclusion of organic residues in the substrate promoted the improvement of chemical, physical and biological properties, creating an adequate environment for root growth and development of whole plants, reducing soil use and consequently, avoiding baits of contamination by pests and diseases. In addition, in addition, it is important to note that land use and consequently avoid risks of contamination by pests and diseases (Sales et al., 2016).

Organic matter also has the ability to alter secondary and secondary metabolism (Biasi et al., 2009), since it provides different beneficial chemicals or non-beneficial elements. In addition, different sources of organic matter can promote different populations of microbiotes and can change the performance of the plant. The use of organic waste from different sources in the production of seedlings may be appropriate to reduce the polluting effect of such waste in addition to being a low-cost organic compound (Berilli et al., 2016).

Table 4. Average values of the leaves number (NF), total length of the plant (CT), roots length (CR), and nitrogen of the root (NR) of Arabica coffee seedlings in different substrates and containers

\begin{tabular}{lllll}
\hline Substrate & NF & NR $(\%)$ & CR $(\mathrm{cm})$ & CT $(\mathrm{cm})$ \\
\hline S1 & $18.00 \mathrm{ab}$ & $1.88 \mathrm{ab}$ & $17.44 \mathrm{ab}$ & $34.88 \mathrm{~b}$ \\
S2 & $16.22 \mathrm{~b}$ & $1.73 \mathrm{ab}$ & $19.33 \mathrm{a}$ & $38.66 \mathrm{a}$ \\
S3 & $19.66 \mathrm{a}$ & $2.19 \mathrm{a}$ & $16.50 \mathrm{~b}$ & $34.44 \mathrm{~b}$ \\
S4 & $18.33 \mathrm{ab}$ & $1.34 \mathrm{~b}$ & $18.11 \mathrm{ab}$ & $35.55 \mathrm{~b}$ \\
\hline
\end{tabular}

Note. Means followed by the the same uppercase letters in the row do not differ significantly among each other by the Tukey test $(\mathrm{p} \leq 0.05)$. S1 convencional; S2 leguminous compound + bovine manure; S3 gramine compound + bovine manure; S4 vermicompost.

In the evaluation of the characters in the containers with different volumes, it was noticed that the containers of greater volumes obtain performance in the studied characters (Table 5). For the characteristics leaf number (NF) and root length (CR) the results were similar for the volume containers of (R1) 615 and (R2) $280 \mathrm{~cm}^{3}$ not differing statistically. The same does not occur for the other variables in which the containers with the largest volume $615 \mathrm{~cm}^{3}(\mathrm{R} 1)$ provided statistically higher values than the other containers evaluated (Table 5).

Table 5. Average values of the number of leaves (NF) total length of the plants (CT);total dry mass (MST); total fresh mass (MFT); length of the aerial plant (CPA); length of the root (CR); height/diameter ratio (ALT/DC); Dickson quality index (DQI), and leaf area (AF) of Arabica coffee palnts in different recipients, and substrates

\begin{tabular}{llllllllll}
\hline \multirow{2}{*}{ Rec. } & \multicolumn{9}{c}{ Variables } \\
\cline { 2 - 10 } & NF & CT & MFT & MST & CPA & CR & ALT/DC & DQI & AF \\
\hline R.1 & $21.25 \mathrm{~A}$ & $45.37 \mathrm{~A}$ & $28.77 \mathrm{~A}$ & $6.26 \mathrm{~A}$ & $24.16 \mathrm{~A}$ & $21.20 \mathrm{~A}$ & $12.10 \mathrm{~A}$ & $0.42 \mathrm{~A}$ & $60.16 \mathrm{~A}$ \\
R.2 & $18.33 \mathrm{~A}$ & $36.25 \mathrm{~B}$ & $11.58 \mathrm{~B}$ & $2.44 \mathrm{~B}$ & $17.25 \mathrm{~B}$ & $18.75 \mathrm{~A}$ & $8.64 \mathrm{~B}$ & $0.24 \mathrm{~B}$ & $27.21 \mathrm{~B}$ \\
R.3 & $14.58 \mathrm{C}$ & $26.29 \mathrm{C}$ & $7.49 \mathrm{~B}$ & $1.92 \mathrm{~B}$ & $12.70 \mathrm{C}$ & $13.58 \mathrm{~B}$ & $6.36 \mathrm{C}$ & $0.21 \mathrm{~B}$ & $18.23 \mathrm{C}$ \\
\hline
\end{tabular}

Note. Means followed by the same uppercase letters in the row do not differ significantly among each other by the Tukey test $(\mathrm{p} \leq 0.05)$. 
Among the characteristics studied of Table 5, it is worth highlighting some characteristics that have a direct correlation with the quality of the seedling among them we can highlight MST, NF, CPA, CR, PA and ALT/DC all ofit's primary to succeed in seedling production directly influencing the quality index seedlings (DQI).

The DQI evaluated for (R1) $615 \mathrm{~cm}^{3}$ containers was 0.42 this value is among the ideal standard for coffee seedlings proposed by (Marana et al., 2008). For Dardengo et al. (2013), this index was efficient to indicate the quality of Conilon with coffee seedlings in different containers $\left(120 \mathrm{~cm}^{3}\right.$ tube and bag of $\left.770 \mathrm{~cm}^{3}\right)$. The values obtained in the present study are close to that mentioned by Dardengo et al. (2013) tostudy the effect of tube size on seedling quality of three forest species. In addition, Ferraz and Engel (2011) observed that the best averages for Dickson's quality index were obtained in larger containers.

\section{Conclusion}

The alternative substrates (Legume compost, Grass compost) were efficient for production of arabica coffee seedlings and can replace the conventional substrate at this development stage, providing good quality seedlings. The major developments were observed in the containers with the highest volume $\left(280 \mathrm{~cm}^{3}\right.$ tube and $615 \mathrm{~cm}^{3}$ bag) and reflected directly on the quality of seedlings.

\section{References}

Baliza, D. P., Oliveira, A. L., Dias, R. A. A., Guimarães, R. J., \& Barbosa, C. R. (2013). Anticipation of the production and development of the coffee crop implanted with different types of seedlings. Coffee Science, $8(1), 61-68$.

Barros, R. S., Maestri, M., Vieira, M., \& Braga Filho, L. J. (1973). Determination of coffee leaf area (Coffea arabica L. cv. 'Bourbon Amarelo'). Revista Ceres, 20(1), 44-52.

Berilli, S. S., Zooca, A. A. F., Rembinski, J., Salla, P. H. H., Almeida, J. D., \& Martineli, L. (2016). Influence of chromium accumulation on secondary compound indexes in conilon coffee seedlings. Coffee Sci., 11(4), 512-520.

Biasi, L. A., Machado, E. M., Kowalski, A. P., Signor, D., Alves, M. A., Lima, F. I., ... Scheer, A. P. (2009). Organic fertilization in the production, yield and composition of the essential oil of the eugenol chemotype. Hortic. Bras., 27(1), 35-39. https://doi.org/10.1590/S0102-05362009000100007

Caldeira, M. V. W., Rosa, G. N., Fenilli, T. A. B., \& Harbs, R. M. P. (2008). Organic compost in the production of aroeira-Vermelha seedlings. Sci. Agrar., 9(1), 27-33. https://doi.org/10.5380/rsa.v9i1.9898

Cogo, F. D., Almeida, S. L. S., Vieira, R. J., Lopes, F. A. B., Campos, K. A., \& Ramalho, A. (2011). Seedling growth of different coffee cultivars as a function of organic fertilization of the substrate. Enciclopédia Biosfera, 7(12), 1-9.

Dardengo, M. C. J. D., de Sousa, E. F., dos Reis, E. F., \& Gravina, G. de A. (2013). Growth and quality of conilon coffee seedlings produced at different containers and shading levels. Coffee Science, 8(4), 500-509.

Dickson, A., Leaf, A. L., \& Hosner, J. F. (1960). Quality appraisal of white spruce and white pine seedling stock in nurseries. The Forestry Chronicle, 36(1), 10-13. https://doi.org/10.5558/tfc36010-1

Ferraz, A. V., \& Engel, V. L. (2011). Effect of tube size on the quality of jatoba seedlings (Hymenaea courbaril L. var. Stilbocarpa yellow (Tabebuia chrysotricha (Mart. Ex DC.) Sandl.) and guarucaia (Parapiptadenia rigida (Benth.) Brenan). Revista Árvore, 35(3), 413-423. https://doi.org/10.1590/S0100-676220110003 00005

Ferreira, D. F. (2011). Sisvar: A computer statistical analysis system. Ciência e Agrotecnologia, 35(6), 1039-1042. https://doi.org/10.1590/S1413-70542011000600001

Gonçalves, E. O., Petri, G. M., Caldeira, M. V. W., Dalmaso, T. T., \& Silva, A. G. (2014). Growth of Ateleia glazioviana seedlings on substrates containing different organic materials. Floresta Ambient, 21(3), 339-348. https://doi.org/10.1590/2179-8087.029213

Jaeggi, M. E. P., Saluci, J. C. G., Rodrigues, R. R., de Amaral Gravina, G., \& de Lima, W. L. (2018). Alternative substrates in different containers for production of conilon coffee seedlings. Coffee Science, 13(1), 80-89. https://doi.org/10.25186/cs.v13i1.1382

Krause, M. R., Lo Monaco, P. A. V., Haddad, I. R., Meneghelli, L. A. M., \& Sousa, T. D. (2017). Utilization of agricultural residues in the composition of substrates for production of tomato seedlings. Horticultura Brasileira, 2, 293-298. 
Marana, J. P., Miglioranza, É., Fonseca, É. D. P., \& Kainuma, R. H. (2008). Quality indexes and growth of coffee seedlings produced in tubes. Ciencia Rural, 38(1), 39-45. https://doi.org/10.1590/S0103-847820080001 00007

Matiello, J. B., Santinato, R., Garcia, A. W. R., Almeida, S. R. A., \& Fernandes, D. R. (2010). Coffee Culture in Brazil: Recommendations Manual. Fundação Procafé, Rio de Janeiro, Brazil.

Meneghelli, C. M., Lo Monaco, P. A. V., Haddad, I. R., Meneghelli, L. A. M., \& Krause, M. R. (2016). Residue of the drying of coffee beans as an alternative substrate in Conilon coffee plants. Coffee Science, 11(3), $330-335$.

Nogueira, A. R. A., \& Souza, G. B. (2005). Laboratory manual: Soil, water, plant nutrition, animal nutrition and food (p. 313). São Carlos: Embrapa Pecuária Sudeste.

Nogueira, G. C. F., Roncatto, G., Ruggiero, C., Oliveira, J. C., \& Malheiros, E. B. (2011). Production of yellow passion fruit seedlings by hipocotyledonous grafting on seven species of passifloras. Rev. Bras. Frutic., 33(1), 237-245. https://doi.org/10.1590/S0100-29452011005000027

Oliveira, C. L. L. G., \& Miglioranza, A. (2015). Quality levels of organic coffee seedlings in black and white nonwoven fabric (NWF) containers of various sizes. African Journal of Agricultural Research, 10(9), 886-894. https://doi.org/10.5897/AJAR2014.9393

Prezotti, L. C., Oliveira, J., Gomes, J., \& Dadalto, G. (2013). Liming and fertilization recommendation manual for the State of Espirito Santo ( $5^{\mathrm{a}}$ aproximação).

Sales, R. A., Ambrozim, C. S., Vitória, Y. T., Sales, R. A., \& Berilli, S. S. (2016). Influência de diferentes fontes de matéria orgânica no substrato de mudas de Passiflora Morifolia. Rev. Encicl. Biosfera., 13(24), 606-6015. https://doi.org/10.18677/EnciBio_2016B_057

Santinato, F., Caione, G., Tavares, T. O., Prado, R. M. (2014). Doses of phosphorus associated with nitrogen on development of coffee seedlings. Coffee Science, 9(3), 419-426.

Soares, A. N. R., Rocha Júnior, V. F. R., Vitória, M. F., \& Silva, A. V. C. (2016). Germination of neem seeds as a function of physiological maturity and substrate. Nucleus, 13(1), 215-222. https://oi.org/10.3738/ 1982.2278.1601

Souza, M. P. S., Costa, A. C., Carreço, R. L. B., \& Lima, W. L. (2013). The valorization of organic waste in the agroecology sector at the Federal Institute of Espírito Santo Campus de Alegre. Cadernos de Agroecologia, $8,1-4$.

Vallone, H. S., Guimarães, R. J., \& Mendes, A. N. G. (2010). Different containers and substrate in the production of coffee seedlings. Ciênc. Agrotecu., 34(1), 55-60. https://doi.org/10.1590/S1413-70542010000100006

\section{Copyrights}

Copyright for this article is retained by the author(s), with first publication rights granted to the journal.

This is an open-access article distributed under the terms and conditions of the Creative Commons Attribution license (http://creativecommons.org/licenses/by/4.0/). 